\title{
Hard Discount Formats Service Quality Assessment Model in Colombia
}

\author{
Juan M. Andrade ${ }^{1}$, Fredy Velez ${ }^{2}$, Elías Ramírez ${ }^{3}$ \\ ${ }^{1}$ Corporación Universitaria Minuto de Dios - Uniminuto, Colombia \\ ${ }^{2}$ Servicio Nacional de Aprendizaje - SENA, Colombia \\ ${ }^{3}$ Universidad Surcolombiana - Usco, Colombia
}

\begin{abstract}
In this article, the construction of an evaluation model of the quality of the service of hard discount stores in Colombia was carried out. Thus, a quantitative study was carried out, under the deductive and descriptive method, with its own instrument designed and supported by the globally accepted Servqual and Servperf models, with Likert-type questions, to measure customer perception. In this regard, around five thousand surveys were applied in the main cities of the country, for the validation of the instrument as the information processing, the quantitative software SPSS-26 and its complement the AMOS were used. The designed model was made up of seven dimensions, namely: tangible elements, reliability, empathy, security, responsiveness, image and loyalty. Finally, it concludes by highlighting the aspects that were considered most relevant for the customers of the discounter's stores.
\end{abstract}

Keywords - quality of service, hard discount stores, evaluation model, Colombia

DOI: $10.18421 /$ TEM111-62

https://doi.org/10.18421/TEM111-62

Corresponding author: Juan M. Andrade,

Corporación Universitaria Minuto de Dios - Uniminuto,

Colombia.

Email: jandradenav@uniminuto.edu.co

Received: 06 December 2021.

Revised: 14 February 2022.

Accepted: 21 February 2022.

Published: 28 February 2022.

(cc) BY-NC-ND(C) 2022 Juan M. Andrade, Fredy Velez \& Elías Ramírez; published by UIKTEN. This work is licensed under the Creative Commons AttributionNonCommercial-NoDerivs 4.0 License.

The article is published with Open Access at https://www.temjournal.com/

\section{Introduction}

At the international level, studies related to the impact of hard discount stores on the economy and consumers in Ecuador [1], their evolution in Germany [2], the defensive strategies of traditional businesses against hard discount formats in the Netherlands [3], the impossibility of conquering the Chinese market [4], among others; however, no studies were found evaluating the quality of the service of these formats.

Nationwide, recent history on hard discount stores is abundant. However, they are mostly focused on the impact generated on the national economy [5] or on the commercial sector in general [6]. Others focused their research on the impact of discounters on neighborhood stores or minimarkets in Bogotá [7] and other cities in the country [8].

From another focus of interest, studies were found related to the success factors attributed to these formats [9], with the motivating factors of their consumers [10] and the influence on consumption habits [11], among other topics [12].

Compared to the studies related to the quality of the service of hard discount stores, a related study was found. Indeed, Borja et al. [13] evaluated the perception of the quality of the service of the hard discount formats, specifically D1 and Justo \& Bueno, in the city of Medellín using the Servqual model.

\section{Literature Review}

\subsection{Quality of Service}

Several authors argue that quality is strongly linked to customer satisfaction, so quality can consider people's needs, especially future ones, and materialize them in a product that provides their satisfaction [14]. Likewise, it is considered that the quality of the service contributes widely to the construction of the competitive advantage of the companies, to the extent that it helps to establish a long-term relationship with the client [15]. 
Parasuraman et al. [16] argue that service quality can be defined as the difference between perceived and expected service, while Mackay and Crompton [17] defined it as "the relationship between the customer's desires for a service and what they perceive they receive" (p. 47).

For their part, Backman and Veldkamp [18] consider that special attention should be paid to measuring the quality of a service and a product, since, although they can be related, there is a marked difference because products can be measured objectively by indicators such as durability and number of defects, compared to services.

In this regard, multiple studies have been developed in the literature on the quality of service, for example, in tourism, in restaurant businesses, in banks and in electronic marketing channels for consumer products, among many other investigations [19], [20].

In general, two schools are distinguished throughout the quality of service studies used in the business sector. The first is the two-dimensional model that measures the technical and functional quality of the services provided inherited from the Nordic school based on the proposal of Grönroos [21]. The second is the five-dimensional Servqual model that measures the tangibility, reliability, responsiveness, security and empathy of the services provided, a proposal of the North American school based on the postulates of Parasuraman et al. [22].

The Nordic school relates quality to corporate image. Likewise, it proposes that quality perceived by the client occurs in two dimensions: technical quality (includes elements such as physical support, material means and internal organization, in other words, what is given to the client) and functional quality (it must see with the development of the service production process, in other words, how the service is provided), and relates them to the corporate image. The latter is a key aspect in perceived quality [23].

Grönroos [21] considers the quality of the service perceived through the experiences evaluated through the dimensions of quality. Thus, the higher the expectations, the more demanding the customer's evaluation will become. The construction of expectations is given according to aspects such as marketing communication, recommendations (word of mouth communication), corporate / local image and customer needs. Therefore, it is essential that the company is responsible in the promise of value that it transmits to the client. Likewise, the contribution of Grönroos [21] stands out regarding the importance of the image of the company in the framework of the evaluation of the quality of the service.

On the other hand, the American school led by Parasuraman et al. [16], [23] took as an initial basis the theory of disconfirmation to carry out their proposals that materialized in the proposal for measuring the perceived quality of service. Initially, the authors' proposal conceived 10 dimensions of the construct: tangible elements, reliability, responsiveness, professionalism, courtesy, credibility, security, accessibility, communication and understanding of the client; however, it was condensed into five dimensions: trust or empathy, reliability, security, responsiveness, and tangibility or tangible elements [24].

The five dimensions proposed by the Servqual model correspond to tangible elements, reliability, responsiveness, security and empathy [24]. Tangible items include components such as company equipment and furnishings, the external appearance of stores, and the appearance of staff and physical facilities [22]. Reliability refers to the compliance and precision of the company to perform the promised service or promise of value [25]. Responsiveness establishes the willingness and speed of the company to help its customers when they ask for it [24]. Security consists of the level of knowledge that employees have, their levels of courtesy and their ability to inspire confidence in their customers [26]. Finally, the empathy dimension refers to the level of personalized attention that the company and its collaborators can provide to customers [25].

Based on the Servqual scale, Cronin and Taylor [27] created an improved scale called Servperf, mainly supported by the assessment of perceptions and composed of 11 items, with which they sought to overcome the criticisms of the Parasuraman et al. [16] model.

Cronin and Taylor [27] state that there is little evidence that clients value the perceived quality of a service in terms of the differences between expectations-perceptions, because there is evidence that shows the tendency to overvalue expectations, with perceptions being the ones that more contribute to the measurement of service quality.

\subsection{Consumer}

The figure of the consumer has been widely discussed in the marketing literature. Hernández [28] defines it as the rational subject who makes decisions about the purchase of products (goods and services), conditioned by their income and oriented towards the optimization of their resources, in order to satisfy their needs.

However, this definition has wide limitations in the conception of the individual's motivation, limiting him almost exclusively to his economic capacity and rational character. Thus, for Gil et al. [29] the consumer moves in an environment in which social, 
economic, political and cultural phenomena coexist that strongly influence the purchase decision or behavior of the consumer. Therefore, the issue must be approached from the perspective of consumer behavior.

The study of consumer behavior raises research on the needs and motivations of individuals, a much more complex area than the exchange activity raised from an economic perspective.

Needs can be defined as a mental process of assessment between what you have today and what you want to have in the future. Maslow proposed one of the most famous theories in this regard, proposing a hierarchical scale of people's needs, starting with the primary ones, linked to physiological aspects, until ascending as psychological superiors are satisfied.

On the other hand, Max-Neef et al. [30] propose a circular model in which the needs and motivations are addressed and satisfied without any preestablished order, rather linked to the individual's own situations.

In general, there are multiple motivations that an individual may have to make the purchase decision, so various factors must be examined, both internal and external, in order to determine it [29].

Another aspect directly linked to consumer behavior is related to the consumer's profile. The customer profile corresponds to the set of social and demographic variables such as age, level of education and geographic location, among others, that can influence purchasing decisions [31].

In the case of discounter's stores, there is little research that determines the motivations of their consumers. However, Quintero [10] found that, within rational decisions, the main motivators were savings and profit maximization. Despite the above, the factors associated with consumers of this type of recent formats are not clear, therefore, it is necessary to describe the commercial dynamics that govern these businesses.

\subsection{Hard Discount Stores or Discounters}

Hard discount stores or discounters were born in Germany in the 1990s, with chains such as Lidl and Aldi. The latter famous for its business model, which even forced Walmart to withdraw from the German market [2].

These formats were conceived as an opportunity within the framework of the economic and financial crises that were experienced in the world at the end of the last century, which was widely used and popularized.

For Duque [23], discounters stores are companies in the retail sector that are characterized by selling a limited assortment of private label products at low prices. Consequently, these types of formats are generally located in densely populated areas of the middle and lower strata. For their part, De los Reyes and Salazar [5] understand it as small businesses that offer a limited number of products from unrecognized brands, which have a lower value and are distributed with a more accessible price for the consumer.

This type of formats has characteristics such as sales areas between 300 and 900 square meters, with a variety of products of less than 1000, among which are the store's own brands and other recognized products, but of an economic line.

\section{Materials and Methods}

The research methodology was synthesized in two stages: the first mentions the approach, the population group and the sample, and the criteria for the analysis of the information, while the second describes the applied quantitative instrument, the operationalization of the variable and its dimensions.

\subsection{Research Overview}

For the case of the present study, its approach was carried out through the deductive method while a theoretical framework that guided the analysis of the phenomenon is approached, that is, the dimensions of the service quality construct that were established [32].

The proposed research had a descriptive scope based on the collection and analysis of information on the perception of service quality.

The research had a population that was made up of around 5,000 customers, people of legal age, of hard discount stores in the main cities of Colombia. The sampling used in the research was Non-Probabilistic and for convenience.

The information gathering process was carried out through a physical questionnaire personally applied by an interviewer to each of the stores' customers. For the information processing, the quantitative statistical software SPSS-26 was used with its AMOS complement for the modeling of structural equations - SEM. As will be seen later, the reliability and validity of the measurement scale contained in the information collection instrument was tested through Cronbach's Alpha Analysis and Confirmatory Factor Analysis (CFA), respectively.

\subsection{Service Quality Analysis Model}

The proposed model is presented in Table 1. composed of seven dimensions of the quality of service in hard discount stores from the constructs proposed by Cronin and Taylor [27], Parasuraman et 
al. [16] [22], Grönroos [21] and Moliner and Berenguer [33]: Tangible elements - T, Reliability R, Empathy - E, Responsiveness - C, Security - S, Image - I and Loyalty - L. (see Table 1.).

Table 1. Questionnaire variables

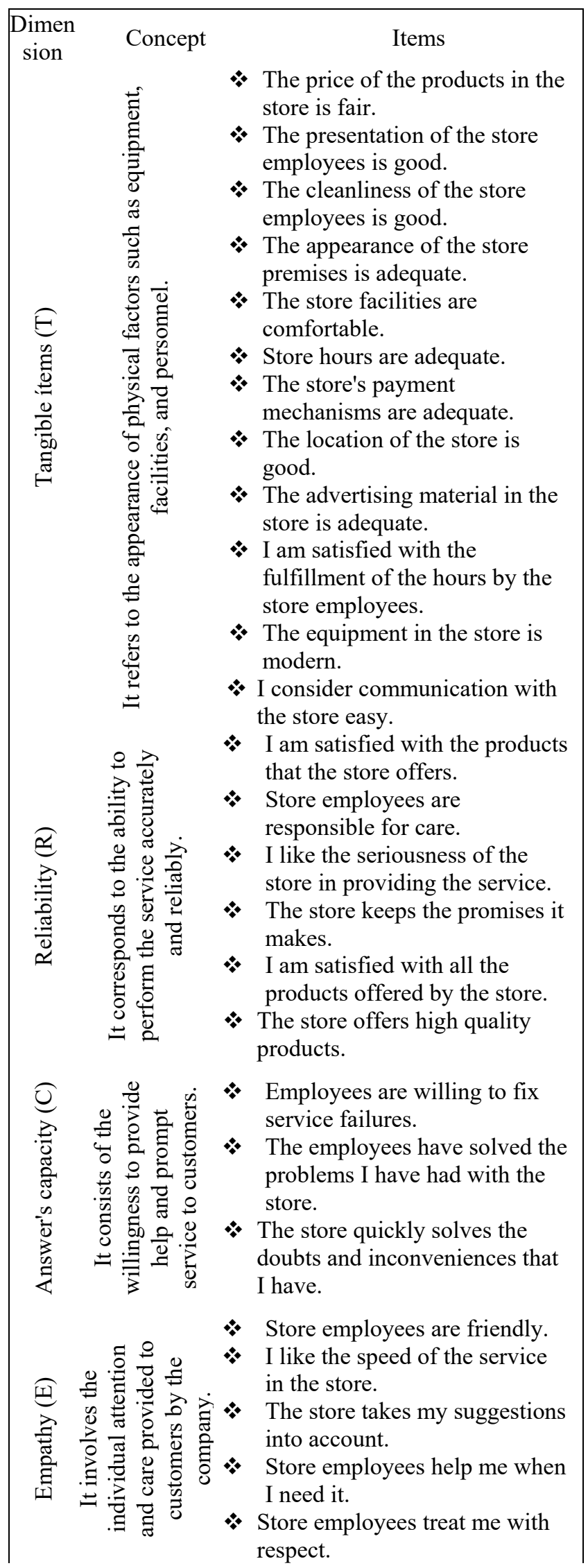

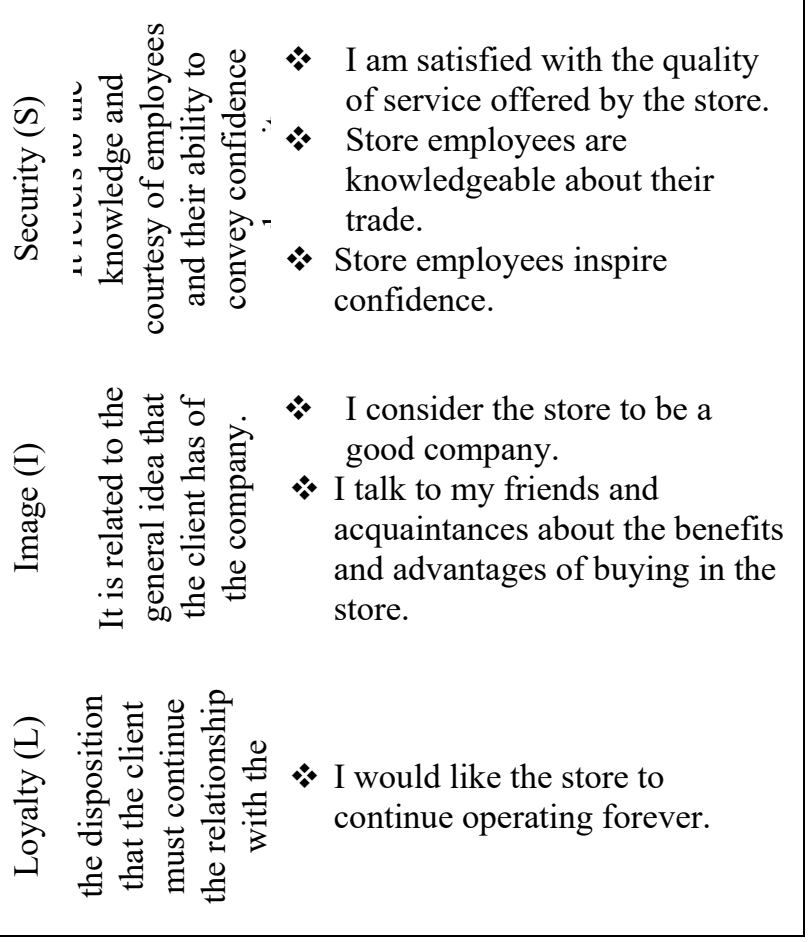

Source: Own elaboration

\section{Results}

Next, the descriptive information and the different analyzes carried out from the collection of the information carried out with respect to the quality of the service of the hard discount stores are presented (see Table 2.).

Table 2. Descriptive analysis of quality of service

\begin{tabular}{|lccccccc|}
\hline & $\mathrm{T}$ & $\mathrm{R}$ & $\mathrm{E}$ & $\mathrm{C}$ & $\mathrm{S}$ & $\mathrm{I}$ & $\mathrm{L}$ \\
Average & 4,13 & 3,95 & 3,97 & 4,11 & 4,03 & 4,14 & 3,72 \\
Mediana & 4,25 & 3,88 & 4,00 & 4,28 & 4,08 & 4,04 & 4,12 \\
Standard &, 602 &, 635 &, 756 &, 676 &, 556 &, 475 &, 546 \\
deviation &, 363 &, 404 &, 573 &, 457 &, 309 &, 321 &, 257 \\
Variance &, 363 \\
\hline
\end{tabular}

Source: Own elaboration

As can be seen in the previous table, the dimensions of the service quality construct applied to hard discount stores obtained a significant average rating, in general, being above or very close to 4 , on a scale of 1 to 5 .

\subsection{Instrument Reliability}

Next, the analyzes taken from the application of the instrument are presented, taking the dimensions of the instrument, and having the same scale that the methodology requires (see Table 3.). 
Table 3. Reliability statistics

\begin{tabular}{|lcc|}
\hline \multicolumn{1}{|c}{ Reliability statistics } & Cronbach's alpha & Items \\
Tangible items - T & $\alpha=0,88$ & 12 \\
Reliability - R & $\alpha=0,88$ & 6 \\
Answer's capacity - C & $\alpha=0,89$ & 3 \\
Empathy - E & $\alpha=0,90$ & 5 \\
Security - S & $\alpha=0,90$ & 3 \\
Image - I & $\alpha=0,90$ & 2 \\
\hline
\end{tabular}

Source: Own elaboration

A more detailed analysis of the reliability of the instrument dimensions was carried out. For the dimensions of the quality of the service of tangible elements with 12 elements it was 0.88 ; reliability with 6 items was 0.88 ; responsiveness with 3 items was 0.89 ; empathy with 5 items was 0.90 ; security with 3 elements was 0.90 ; image with 2 elements was 0.90 . As can be seen, in all cases the coefficients represent an adequate index of convergence.

\subsection{Confirmatory Factor Analysis}

On the other hand, the Confirmatory Factor Analysis (CFA) of the latent variable model was performed since it is a multidimensional variable; that is, it is composed of different dimensions. Next, the Confirmatory Factor Analysis of the quality of service variable is presented because it is a construct composed of seven dimensions.

The proposed model has seven dimensions of the service quality variable, as it seeks to verify the seven-dimensional structure proposed by Cronin and Taylor [27], Parasuraman et al. [16] [22], Grönroos [21] and Moliner and Berenguer [33]: Tangible elements - T, Reliability - F, Empathy - E, Responsiveness - C, Security - S, Image - I and Loyalty - L. Table 4 . shows the values of the goodness of fit indices for the proposed model. In this regard, for the analyzed model the chi-square was significant $(\chi 2[259, \mathrm{~N}=5000]=873.721 ; \mathrm{p}$ $<0.00$ ), the other adjustment indices, such as GFI, AGFI and CFI reached high values in the model, while the RMSEA error index showed reduced values. This result is consistent with the initially proposed multidimensional structure, which is why the model is considered to have a good fit. Finally, given the results of the CFA, it was decided not to eliminate any item for subsequent analyzes.
Table 4. Adjustment indices of the CFA model of the quality of service variable

\begin{tabular}{|ccc|}
\hline Index & $\begin{array}{c}\text { Estimated } \\
\text { Model }\end{array}$ & Acceptance Level \\
Chi squared & 873,721 & $\mathrm{P}<0,00$ \\
Df & 278 & \\
CMIN/DF & 2,744 & $<3,00$ \\
CFI & 0,905 & $>0,90$ \\
TLI & 0,889 & $>0,90$ \\
IFI & 0,906 & $>0,90$ \\
RFI & 0,894 & $>0,90$ \\
NFI & 0,913 & $>0,90$ \\
GFI & 0,902 & $>0,90$ \\
AGFI & 0,821 & $>0,80$ \\
RMSEA & 0,073 & $\leq 0,08$ \\
\hline
\end{tabular}

Source: Own elaboration

\subsection{Validation of the Structural Model}

The model evaluated the relationship between the service quality construct and the dimensions of tangible elements $(0.709 ; \mathrm{p}<0.00)$, reliability $(0.657$; $\mathrm{p}<0.00)$, empathy $(0.784 ; \mathrm{p}<0.00)$, security $(0.851$; $\mathrm{p}<0.00)$, responsiveness $(0.652 ; \mathrm{p}<0.00)$, image $(0.682 ; \mathrm{p}<0.00)$ and loyalty $(0.813 ; \mathrm{p}<0.00)$.

As can be seen in Table 5., there is a positive and significant relationship between the dimensions and the quality of the service. However, it is noted that in the hypothesized model it was decided to eliminate the analyzes for items T1, T2, T12 and F6 due to their low load.

Table 5. Analysis of hypothesized relationships

\begin{tabular}{|cc|}
\hline Relationship & $\begin{array}{c}\text { Estimated } \\
\text { Proposed model } \\
\mathrm{T} \rightarrow \mathrm{SQ}\end{array}$ \\
$\mathrm{F} \rightarrow \mathrm{SQ}$ &, $709^{* * *}$ \\
$\mathrm{E} \rightarrow \mathrm{SQ}$ &, $657^{* * *}$ \\
$\mathrm{C} \rightarrow \mathrm{SQ}$ &, $684^{* * *}$ \\
$\mathrm{~S} \rightarrow \mathrm{SQ}$ &, $652^{* * *}$ \\
$\mathrm{I} \rightarrow \mathrm{SQ}$ & $681^{* * *}$ \\
$\mathrm{~L} \rightarrow \mathrm{SQ}$ &, $813^{* * *}$ \\
\hline
\end{tabular}




\section{Conclusions}

This research was carried out with the objective of designing and validating a model to evaluate the level of service quality perceived by customers of the hard discount or hard discount formats in Colombia in 2021. Thus, a Likert scale-type instrument was designed, which contained seven dimensions, namely: tangible elements, reliability, empathy, security, responsiveness, image and loyalty.

Against the hypothesized structural model, it was possible to verify its good fit and the significant and positive relationship between the seven proposed dimensions and the service quality construct for hard discount stores. Likewise, the levels of convergent validity and reliability obtained in the model were acceptable.

The dimensions of security, loyalty and empathy were those that showed a greater correlation within the quality of service construct of these formats. Although in general, the correlation was good for all dimensions, the responsiveness had the lowest level of relationship. It is necessary to continue with the application of the instrument in order to improve it, especially within the Latin American sphere.

\section{References}

[1]. Morocho, X.G. \& Noblecilla, J.G. (2019). Tiendas de gran descuento "Hard discount" y su incidencia en el poder adquisitivo del consumidor. Universidad Católica de Santiago de Guayaquil, Ecuador.

[2]. Wortmann, M. (2021). The German variety of grocery retailing: A historical institutionalist analysis of a non-core industry. Competition \& Change, 25(3-4), 453-477.

https://doi.org/10.1177/1024529420941138

[3]. Guyt, J. Y., \& Gijsbrechts, E. (2020). Evaluating the effectiveness of retailer-themed super saver events. Journal of Marketing, 84(2), 92-113. https://doi.org/10.1177\%2F0022242919896334

[4]. Hardaker, S. (2018). Retail format competition: The case of grocery discount stores and why they haven't conquered the Chinese market (yet). Moravian Geographical Reports, 26(3), 220-227. https://doi.org/10.2478/mgr-2018-0018

[5]. De los Reyes Mercado, J. D., \& Araujo, E. S. (2017). El discount y sus efectos en la economía de mercado. Liderazgo Estratégico, 7(1), 11-23.

[6]. Martinez, L. \& Ricaurte, M. (2019). El efecto que ha traído sobre los consumidores la entrada de los hard discounters en Bogotá frente a los principales canales de retail entre las calles 106 y 140 entre la carrera 7ma y autopista norte. [Trabajo de Investigación, Colegio de Estudios Superiores de Administración CESA] Repositorio CESA.
[7]. Sánchez Duarte, L. A. (2018). El impacto de los establecimientos Hard Discount o tiendas de descuento en el sector comercial de Colombia. Retrieved from:

https://ciencia.lasalle.edu.co/administracion_de_empr esas/1593 [accessed: 10 October 2021].

[8]. Molina Valencia, R. G., Millán, G., Millán, O. U. G., \& Javie, J. (2019). Tiendas Hard Discount y su incidencia en los minimercados boyacenses. Revista Venezolana de Gerencia, 2, 573-589. https://doi.org/10.37960/revista.v24i2.31511

[9]. Ospina Espinosa, J. M., Zambrano Nieto, S. M., \& Zambrano Nieto, W. A. (2020). Variables de éxito e influencia de tiendas tipo Hard Discount en BogotáColombia (Bachelor's thesis, Universidad EAN).

[10]. Quintero Cruz, S. M. (2019). Rol de los motivadores de compras de productos marca propia en los formatos Hard Discount de los estratos 3, 4, 5 Y 6 de la ciudad de Medellín (Doctoral dissertation, Universidad EAFIT).

[11]. Estrada, S. H. (2019). La influencia de los discounter en el cambio de hábitos de consumo de los colombianos. Revista ADGNOSIS, 8(8). https://doi.org/10.21803/adgnosis.v8i8.366

[12]. Hökelekli, G., Lamey, L., \& Verboven, F. (2017). The battle of traditional retailers versus discounters: The role of PL tiers. Journal of Retailing and Consumer Services, 39, 11-22. http://dx.doi.org/10.1016/j.jretconser.2017.06.011

[13]. Calderón, J. A. B., Restrepo, É. M. M., \& BermúdezHernández, J. (2019). Percepción de la calidad del servicio prestado por los supermercados tipo hard discount (D1 y Justo \& Bueno) en la ciudad de Medellín a partir del modelo Servqual. Revista CIES Escolme, 10(2), 165-184.

[14]. Murray, D., \& Howat, G. (2002). The relationships among service quality, value, satisfaction, and future intentions of customers at an Australian sports and leisure centre. Sport Management Review, 5(1), 2543. https://doi.org/10.1016/S1441-3523(02)70060-0

[15]. Díaz, H. O. A. (2017). La calidad en el servicio como ventaja competitiva. Dominio de las Ciencias, 3(2), 72-83. DOI: $10.23857 /$ dc.v3i3 mon.627

[16]. Parasuraman, A., Zeithaml, V. A., \& Berry, L. L. (1985). A conceptual model of service quality and its implications for future research. Journal of marketing, 49(4), 41-50.

[17]. MacKay, K. J., \& Crompton, J. L. (1990). Measuring the quality of recreation services. Journal of Park and Recreation Administration, 8(3), 47-56.

[18]. Backman, S. J., \& Veldkamp, C. (1995). Examination of the relationship between service quality and user loyalty. Journal of park and recreation administration, 13(2), 29-41.

[19]. Ananda, S. \& Devesh, S. (2019). Service quality dimensions and customer satisfaction: empirical evidence from retail banking sector in Oman. Total Quality Management and Business Excellence, 30(1516), 1616-1629. https://doi.org/10.1080/14783363.2017.1393330 
[20]. Miranda Velloso, C., Magueta, D., Barbosa Sousa, B., \& Carvalho, J. L. (2020). Meassevuring E-Service Quality, Satisfaction and Loyalty of Customer in the Online Channel of the Modern Retail. IBIMA Business Review. DOI: $10.5171 / 2020.531781$

[21]. Gronroos, C. (1984). A Service Quality Model and its Marketing Implications. European Journal of Marketing, 18(4), 36-44. https://doi.org/10.1108/EUM0000000004784

[22]. Parasuraman, A., Zeithaml, V. A., \& Berry, L. (1988). SERVQUAL: A multiple-item scale for measuring consumer perceptions of service quality. 1988, 64(1), 12-40.

[23]. Duque Oliva, E. J. (2005). Revisión del concepto de calidad del servicio y sus modelos de medición. Innovar, 15(25), 64-80.

[24]. Hussain, R., Al Nasser, A., \& Hussain, Y. K. (2015). Service quality and customer satisfaction of a UAEbased airline: An empirical investigation. Journal of Air Transport Management, 42, 167-175. https://doi.org/10.1016/j.jairtraman.2014.10.001

[25]. Ramanathan, U., Win, S., \& Wien, A. (2018). A Servqual approach to identifying the influences of service quality on leasing market segment in the German financial sector. Benchmarking, 25(6), 19351955. https://doi.org/10.1108/BIJ-12-2016-0194

[26]. Wetzel, P., \& Hofmann, E. (2020). Toward A MultiSided Model of Service Quality for Logistics Service Providers. Administrative Sciences, 10(79), 1-24. DOI: $10.3390 /$ admsci10040079
[27]. Cronin Jr, J. J., \& Taylor, S. A. (1992). Measuring service quality: a reexamination and extension. Journal of marketing, 56(3), 55-68. https://doi.org/10.1177\%2F002224299205600304

[28]. Fernández, A. H. (2012). El valor percibido por el consumidor: conceptualización y variables relacionadas. Camino para el éxito de un negocio. $3 c$ Empresa: investigación y pensamiento crítico, 1(4), 2.

[29]. Gil Hernández, C. Y., Torres Estrada, I. C., \& López Torres, Z. A. (2013). Dimensión integral e interdisciplinaria del concepto de comportamiento del consumidor. Anagramas-Rumbos y sentidos de la comunicación-, 11(22), 179-200. https://doi.org/10.22395/angr.v11n22a10

[30]. Max-Neef, M., Elizalde, A., Hopenhayn, M., Herrera, F., Zemelman, H., Jatobá, J. \& Weinstein, L. (1993). Desarrollo a Escala Humana: una opción para el futuro. Santiago de Chile: Cepaur.

[31]. Holguín, J.A. \& Osorio J. (2018). Hábitos de compra de los clientes actuales de las tiendas de descuento Ara y A1 de la zona céntrica de Pereira. Universidad Católica de Pereira, Colombia.

[32]. Prieto Castellanos, B. J. (2017). El uso de los métodos deductivo e inductivo para aumentar la eficiencia del procesamiento de adquisición de evidencias digitales. Cuadernos de contabilidad, 18(46), 56-82.

https://doi.org/10.11144/Javeriana.cc18-46.umdi

[33]. Moliner Velázquez, B., \& Berenguer Contrí, G. (2011). El efecto de la satisfacción del cliente en la lealtad: aplicación en establecimientos minoristas. Cuadernos de administración, 24(42), 73100. https://doi.org/10.11144/Javeriana.cao24-42.escl 